Max-Planck-Institut für demografische Forschung

Max Planck Institute for Demographic Research

Konrad-Zuse-Strasse 1 - D-18057 Rostock - GERMANY

Tel +49 (0) 3812081 - 0; Fax +49 (0) 3812081 - 202;

http://www.demogr.mpg.de

MPIDR WORKING PAPER WP 2013-001

JANUARY 2013

\title{
Providing Easy Access to Cross-Country \\ Comparative Contextual Data for Demo- graphic Research: Concept and Recent Advances of the Generations \& Gender Programme Contextual Database
}

\author{
Arianna Caporali \\ Sebastian Klüsener (kluesener@demogr.mpg.de) \\ Gerda Neyer \\ Sandra Krapf \\ Olga Grigorieva
}

This working paper has been approved for release by: Mikołaj Szołtysek (szoltysek@demogr.mpg.de), Deputy Head of the Laboratory of Historical Demography.

(C) Copyright is held by the authors.

Working papers of the Max Planck Institute for Demographic Research receive only limited review. Views or opinions expressed in working papers are attributable to the authors and do not necessarily reflect those of the Institute. 


\section{Providing Easy Access to Cross-Country Comparative Contextual Data for}

Demographic Research: Concept and Recent Advances of the Generations \& Gender Programme Contextual Database

Arianna Caporali ${ }^{1}$, Sebastian Klüsener ${ }^{2}$, Gerda Neyer $^{3}$, Sandra $\operatorname{Krapf}^{2}$, Olga Grigorieva ${ }^{2}$

${ }^{1}$ Service des enquêtes et sondages, Institut national d'études démographiques (Ined, France).

${ }^{2}$ Max Planck Institute for Demographic Research (MPIDR, Germany).

${ }^{3}$ Stockholm University, Demography Unit (SUDA, Sweden). 


\title{
Contents
}

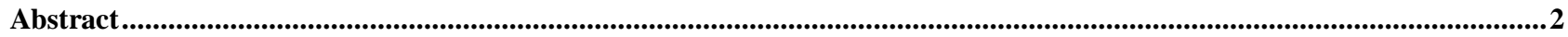

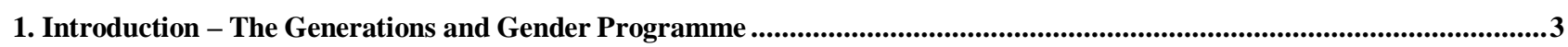

2. Contextualising individual behaviour - Conceptual framework and content of the GGP Contextual Database .....................5

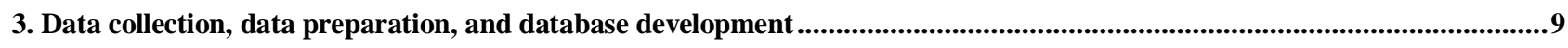

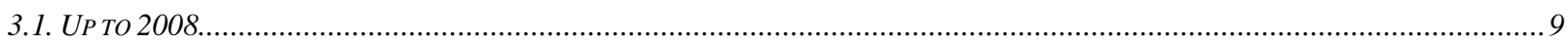

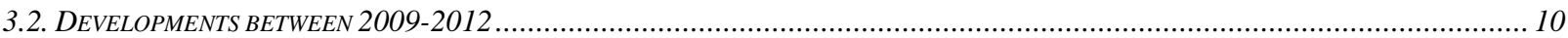

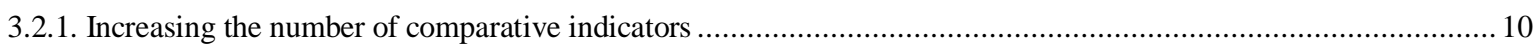

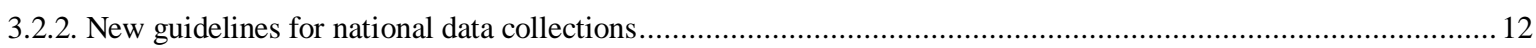

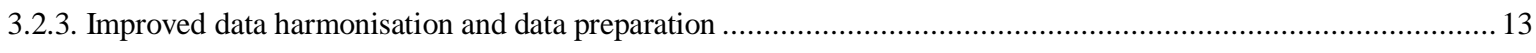

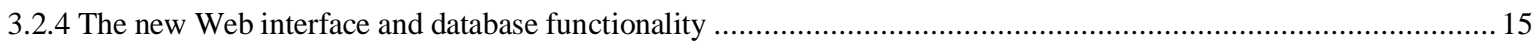

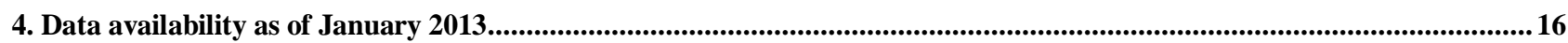

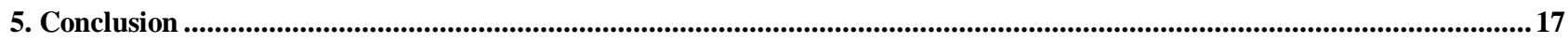

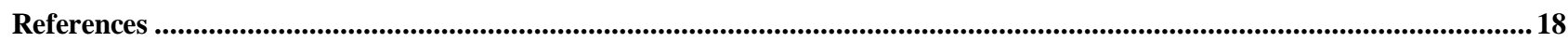

Appendix A: An extract from the variable-by-variable overview of data in the Contextual Database and other international

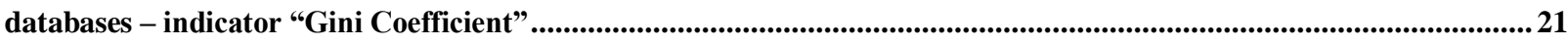

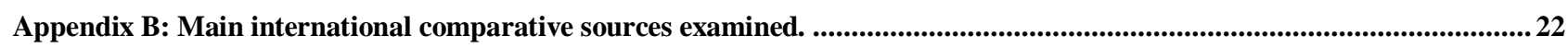

Appendix C: Extract from the new guidelines for national data collectors ...................................................................24

Appendix D: Combination of national sources with international sources - indicator "Mean Age at Birth", Lithuania ..........26

Appendix E: Combination of international sources with other international sources - indicator "Labour Force

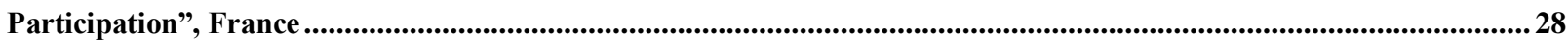

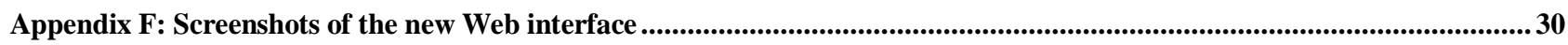

\begin{abstract}
Demographic behaviour is shaped not only by characteristics at the individual level, but also by the context in which individuals are embedded. The Contextual Database of the Generations and Gender Programme (GGP) supports research on these micro-macro links by providing crosscountry comparative contextual data on demographic, socio-economic, and policy developments covering up to 60 countries in Europe, North America, Asia, and Oceania. This paper presents conceptual considerations and recent advances in the implementation of this database. Although conceptually linked to the Generations and Gender Survey, the GGP Contextual Database can also be used for the analysis of data from other surveys or to study macro-developments. With its unique combination of features, this database could serve as a model for the development of contextual databases linked to other surveys. These features include the provision of harmonised national and sub-national regional time series of indicators in a dynamic web environment with innovative functionalities, such as metadata documentation by single data entry and automatic geocoding.
\end{abstract}




\section{Introduction - The Generations and Gender Programme}

Demographic aspects, such as increasing life expectancy and low fertility, present policy challenges for many national governments in Europe and other industrialised countries. To meet these challenges, policy makers need a better understanding of individual behaviour, as well as of the social, economic, demographic, and policy-related factors that influence these developments. In studying these issues, researchers must have access not only to cross-country comparative individual data on demographic behaviour, but also to information on the contextual political and socio-economic conditions in which this behaviour is embedded. However, it can be a tedious and time-consuming endeavour for researchers to compile cross-country comparative contextual data by themselves. Data often have to be derived from different international and national databases, and then checked for reliability and comparability. The Contextual Database (CDB) of the Generations and Gender Programme (GGP) assists researchers in this task by providing them with easy access to harmonised cross-country comparative data on demographic, socio-economic, and policy contexts.

The CDB is an integral part of the GGP, which aims to provide internationally comparable individual-level data on demographic behaviours and contextual information on demographic, social, economic, and political macro-conditions. The main focus of the GGP is on Europe, but it also covers developed countries of other continents, such as Japan and Australia. The central topics of the programme are fertility, partnership, transition to adulthood, and economic activity; as well as intergenerational and gender relations between people, as expressed in care relationships or the organisation of paid and unpaid work. For example, the GGP data allow us to investigate the reasons for low fertility in large parts of Europe and Asia, or the ways in which welfare states support the family in light of the profound transformations that families and family relationships are undergoing.

The GGP was initiated by the Population Unit (PU) of the United Nation's Economic Commission of Europe (UNECE) at the 2000 Geneva meeting on Generations and Gender (United Nations 2007, 2008, 2009). To develop the Programme, PU formed the GGP Consortium Board, which brought together the considerable resources of Europe's largest demographic institutions and statistical offices $^{4}$. To map the field of the GGP, four conceptual papers were developed at the launch of the

\footnotetext{
${ }^{4}$ Since 2009, the Netherlands Interdisciplinary Demographic Institute (NIDI) has been in charge of the co-ordination of the project. At the national level, GGP National Committees deal with the implementation of the Programme. The Consortium is composed of 11 institutions: Netherlands Interdisciplinary Demographic Institute (NIDI), Institut
} 
programme to discuss the research and data collection on children and adolescents, the working-age population, older people, and intergenerational relationships (United Nations 2000). The GGP was the continuation of the Comparative Fertility Study (CFS), which was concluded in the mid-1970s; the World Fertility Survey (WFS), which came thereafter; and the Fertility and Family Survey (FFS) project, which was conducted in the 1990s (Festy 2004). The GGP introduced a number of innovations that distinguish it from its predecessors. The programme's goal is to be "prospective, multidisciplinary, context-sensitive and highly comparative" (Macura 2002: 6). The GGP is built around the Generations and Gender Survey (GGS), a longitudinal survey that breaks with the tradition of cross-sectional surveys. From its inception, the GGP has been a multi-country effort to develop a joint comparative project based on a multidisciplinary approach to the interactions between generations and gender, and to their effects on child-parent relationships and partnerpartner relationships.

The GGS represents the core element of the GGP. It is a panel survey conducted at intervals of approximately three years. The respondents are individuals between the ages of 18 and 79 who do not live in institutions (see Vikat et al. 2007 for details). The primary aim of the survey is to help explain the process of leaving home, partnership dynamics, childbearing, and retirement. To this end, it collects retrospective data on individuals' mezzo context (e.g., questions on the parental home during childhood). The prospective focus is maintained through a standard block of questions on intentions. The domains covered in the survey include economic aspects of individuals' lives (e.g., economic activity, income, and economic well-being), values and attitudes regarding family and fertility changes, intergenerational relationships, gender relationships, household composition and housing, residential mobility, social networks and private transfers, education, health, and public transfers.

The GGP was one of the first survey programmes to combine for each participating country the micro-level data collection of the GGS with the macro- (national) and meso-level (regional) data collection of the CDB (Festy 2004; Macura 2002; Vikat et al. 2007). These contexts-which are defined as national policies, educational systems, labour and housing markets, regional and local conditions, and social groups - determine the opportunity structures that affect an individual's life

national d'études démographiques (Ined, France), Carlo F. Dondena Centre for Research on Social Dynamics of Bocconi University (Italy), Statistics Norway, Demographic Research Institute of the Hungarian Central Statistical Office (Hungary), NOVA (Norway), Faculty of Social Sciences of the University of Ljubljana (Slovenia), Utrecht University (Netherlands), Department of Social Policy of the University of York (Great Britain), Max Planck Institute for Demographic Research (MPIDR, Germany), Erasmus University Rotterdam (Netherlands), PU - UNECE. 
course and critical transitions (e.g., transition to adulthood, parenthood, retirement). The CDB aims to provide ready-to-use, cross-country comparative data on these topics for the 56 countries covered by the United Nations Economic Commission for Europe (UNECE), and beyond.

The importance of enhancing micro-level data with macro-level information has already been emphasised in conjunction with the FFS (Goldscheider 2000), which provided a small static macrodata collection on its webpage. The first explorative studies on database design and information context were conducted within the GGP International Working Group (Festy 2001). These studies underlined the need for defining, both conceptually and statistically, the context not only of intergenerational relationships, but also of gender relationships; they also recommended cooperating with national experts in the identification of adequate international comparative concepts and statistics. In 2002, a GGP-CDB Working Group ${ }^{5}$ was set up to develop the database on the basis of theoretical and methodological background papers (Bisogno 2002; Festy 2002; Neyer 2002; Racioppi and Rivellini 2002). The group discussed not only conceptual, but also practical and organisational issues (Festy 2004). These considerations served as a blueprint for the implementation of the CDB, which has been co-ordinated since 2003 by the Max Planck Institute for Demographic Research (MPIDR), based in Rostock (Germany).

\section{Contextualising individual behaviour - Conceptual framework and content of the GGP Contextual Database}

A four-way approach guided the development of the CDB conceptual framework and content. First, the content of the GGS questionnaire served as a starting point for determining the relevant contextual domains (Festy 2002). Following a life course perspective, the micro-level information of the survey was structured around five main careers: (1) life career, (2) activity career, (3) residential career, (4) partnership career, and (5) fertility career. For each life course segment, a corresponding contextual domain for the CDB was identified (Spielauer 2004a). For instance, individual choices concerning parenthood were placed into macro contexts, such as the maternity

\footnotetext{
${ }^{5}$ The group was headed by Patrick Festy from Ined. Members of the group included: Antonella Pinnelli and Filomena Racioppi ("La Sapienza", University of Rome, Italy), Giulia Rivellini (University of Milan, Italy), Gerda Neyer (MPIDR, Germany), Lars Østby (Statistics Norway), Jacques Légaré (Statistics Canada), Martin Spielauer (Austrian Institute for Family Studies, Oif), Teresa Munzi (Luxembourg Income Study, LIS), Enrico Bisogno, Martine Corijn, Miroslav Macura and Alphonse McDonald (PU, UNECE), Mark Pearson (Organization for Economic Co-operation and Development, OECD), Pau Baizan (University of Barcelona) and Gösta Esping-Andersen (University of Barcelona).
} 
leave system, job protection, and the birth preparation system. These contexts may vary considerably across countries.

The second approach was concerned with theories and hypotheses that relate to the GGS key dependent variables, which are childbearing, partnership formation and dissolution, transition to adulthood, living arrangements, and economic activity (Spielauer 2004a, 2007). The contextual domains were intended to encompass the dimensions used in the GGS to investigate gender and inter-generation relations (i.e., legal, co-residence, intensity, quality, power and decision-making, care relations, economic exchange), the socio-economic situation and the welfare state (i.e., jobs and the labour market, non-labour income, wealth, expenditures on care, and household services), attitudes and value orientations towards the domains studied, and religiosity. Two overlapping concepts of context were supposed to influence individual behaviours. While the macroeconomic situation and cultural, religious, and social norms may affect individual choices, state policies impose regulations that may also have an impact on individual life courses (e.g., education regulations) (Spielauer 2004a, 2007).

To develop a conceptual framework for the collection of policy data, Neyer (2003) analysed concepts from comparative welfare state research theories. She clustered key measurement dimensions of policies around four main concepts: (1) equality, (2) agency, (3) social rights, and (4) risks and security. For example, levels of equality may be measured based on income distribution and the public representation of different groups of the population (e.g., women's labour force participation or the representation of women in the political arena). Agency may be evaluated based on the degree of access to social services (e.g., care services) and national social expenditures. Social rights may be measured in terms of entitlements to the rights provided, while risk and security may be captured in terms of the distribution of social security (e.g., health, unemployment, maternity). Drawing from feminist welfare state research, Neyer (2003) further emphasised the importance of considering how policies shape gender (and inter-generational) relations.

The third approach explored the methodological issues involved in the data analysis. To enable researchers to conduct multi-level comparative studies in combination with GGS micro-level data, the $\mathrm{CDB}$ had to match the retrospective, prospective, and geographical information collected in the survey (Racioppi and Rivellini 2002). In addition, it had to allow for the linkage over time between individuals and their geographical context, and between them and their membership groups. Furthermore, the data had to be comparative across countries. The fourth and final approach began 
with an inventory of existing international comparative databases (Bisogno 2002; Neyer 2003; Spielauer 2004a), which was designed to provide information about data availability and past experiences in conceptual framework development and data collection. Neyer (2003) screened all of the relevant databases that contained policies to determine whether they should be included and collected for GGP purposes.

The combination of these four approaches led to the identification of more than 200 variables structured around 16 key topics (see Fig. 1). Among the CDB variables, there are around 95 national-level time series and 60 policy indicators. The time series are primarily yearly numeric variables, while the policy histories provide standardised descriptions of key policy changes over time. To match the retrospective depth of the GGS, all of the indicators would have to go back to 1970 or earlier. Moreover, the CDB includes around 65 sub-national regional variables, with the goal of capturing the sub-national variation of contexts. As it might be particularly difficult to obtain long time series for sub-national regional indicators, the focus of the data collection activities for these indicators is on the period after 2000. The level of geographic detail at which the subnational regional data are provided varies across countries. It depends on the sample size requirement for multi-level analysis, the availability of sub-national data, and the level of geographic regional detail at which the identifier for the place of residence of an interviewed person is given in the national GGS. Ultimately, to meet the criteria of the generations and gender dimensions of the GGS, most contextual indicators are collected by sex and age groups. Being a cross-country comparative database, variables are defined according to international definitions. National variable definitions may only be applied in cases in which comparable data across countries are not available.

Fig. 1 Overview - Indicators in the Contextual Database by Domain

\begin{tabular}{|c|l|l|l|}
\hline Domains & \multicolumn{1}{|c|}{ National-level indicators } & Regional-level indicators & \multicolumn{1}{|c|}{ Policy histories } \\
\hline \multirow{5}{*}{ 1. Demography } & $\begin{array}{l}\text { Total fertility rate, Live births, Marital live births, } \\
\text { Mean age at birth for all and first (live) births, Age- } \\
\text { specific fertility rates, Cohort mean age at all and first } \\
\text { (live) births, Completed cohort fertility, Induced legal } \\
\text { abortions, Proportion of childless women by birth } \\
\text { cohort. Mean age at first marriage, No. of marriages, } \\
\begin{array}{l}\text { First marriages by 1000 women by age group, } \\
\text { Proportion of ever-married women at age 50 by birth } \\
\text { cohort, Marriage matrix by important ethnic or } \\
\text { national groups, Children with single mothers and } \\
\text { fathers by age group, No. of divorces, Total divorce } \\
\text { rate, Median duration of marriage at divorce. Life } \\
\text { expectancy at specific ages. International net migration } \\
\text { by 10,000, Marital status by age group and sex, Total } \\
\text { birthe } \\
\text { population by age group and sex, Median age by sex. } \\
\text { - male \& female, No. of } \\
\text { marriages, First marriages, } \\
\text { Children with single mothers } \\
\text { and fathers by age group, No. of } \\
\text { divorces, Marital status by age } \\
\text { group - male \& female, Total } \\
\text { male \& female population by } \\
\text { age group. }\end{array}\end{array}$ & No policy histories. \\
\hline
\end{tabular}


Fig. 1 (Continued).

\begin{tabular}{|c|c|c|c|}
\hline Domains & National level indicators & Regional level indicators & Policy Histories \\
\hline $\begin{array}{l}\text { 2. Economic \& } \\
\text { social system }\end{array}$ & $\begin{array}{l}\text { Real GDP per capita, Consumer Price Index, GINI } \\
\text { coefficient of income distribution, Poverty by age and } \\
\text { sex, Poverty by activity status and sex, Poor } \\
\text { households by household type. }\end{array}$ & $\begin{array}{l}\text { Household income deciles, } \\
\text { Poverty line, Children aged 0-14 } \\
\text { living in poor households, } \\
\text { Mothers of children aged } 0-14 \\
\text { living in poor households, } \\
\text { People aged } 15-64 \text { living in poor } \\
\text { hou seholds, People aged } 65+ \\
\text { living in poor households, } \\
\text { People living in poverty. }\end{array}$ & Poverty definition. \\
\hline $\begin{array}{l}\text { 3. Labour } \\
\text { market and } \\
\text { employment }\end{array}$ & $\begin{array}{l}\text { Labour market participation by sex, Sectoral } \\
\text { employment by ISIC activity and sex, Public } \\
\text { employment as percentage of people in labour force, } \\
\text { Employment by ISCO-88 occupational group and sex, } \\
\text { Distribution of employed persons by usual weekly } \\
\text { hour bands and by sex, Average vacation days per year } \\
\text { of employees, Average wage by ISIC activity and sex, } \\
\text { Minimum monthly wage, Average wage by age and } \\
\text { sex, Wage income deciles by sex, Public expenditure } \\
\text { for active labour market programs. }\end{array}$ & $\begin{array}{l}\text { Labour market participation by } \\
\text { age group and sex, Employment } \\
\text { of mothers and fathers by age of } \\
\text { youngest child, Public } \\
\text { employment by age and sex, } \\
\text { Average monthly wages, } \\
\text { Average wages by age group } \\
\text { and sex, Wage income deciles } \\
\text { by sex. }\end{array}$ & $\begin{array}{l}\text { Regulations on working hours and } \\
\text { paid vacation days per year, Measures } \\
\text { on part-time work. }\end{array}$ \\
\hline $\begin{array}{l}\text { 4. Parental } \\
\text { Leave }\end{array}$ & $\begin{array}{l}\text { Average or typical take-up times of child-related leave } \\
\text { programs. }\end{array}$ & No regional level indicators. & $\begin{array}{l}\text { Comparative table of maternity, } \\
\text { parental, and childcare leave } \\
\text { programs, Descriptions of leave } \\
\text { programs for sick children. }\end{array}$ \\
\hline $\begin{array}{l}\text { 5. Pension } \\
\text { system }\end{array}$ & $\begin{array}{l}\text { Average retirement age by sex, Minimum pension per } \\
\text { type, Public pension spending as } \% \text { of GDP, Persons } \\
\text { receiving old age, survivors and disability pensions, } \\
\text { Average old age pension by sex. }\end{array}$ & Average old age pension by sex. & $\begin{array}{l}\text { General description of the pension } \\
\text { system, Regular legal and early } \\
\text { retirement age, Mechanism that links } \\
\text { pension contributions to benefits, } \\
\text { Consequences of child and family } \\
\text { care periods on pensions. }\end{array}$ \\
\hline $\begin{array}{l}\text { 6. Childcare } \\
\text { policies and } \\
\text { institutions }\end{array}$ & $\begin{array}{l}\text { Enrolment rates in childcare institutions, Child-staff } \\
\text { ratio, Public pre-school childcare expenditure. }\end{array}$ & $\begin{array}{l}\text { Percentage of children living in } \\
\text { institutions by age group. }\end{array}$ & $\begin{array}{c}\text { Description of main childcare } \\
\text { institutions and arrangements, Legal } \\
\text { entitlement to childcare, Preschool: } \\
\text { availability and entry age, typical } \\
\text { opening hours, requirements of } \\
\text { childcare staff. } \\
\end{array}$ \\
\hline $\begin{array}{l}\text { 7. Military and } \\
\text { alternative } \\
\text { civilian service } \\
\text { system }\end{array}$ & $\begin{array}{l}\text { People in armed forces, Military expenditure as } \% \text { of } \\
\text { GDP. }\end{array}$ & No regional level indicators. & \begin{tabular}{|l} 
General description of national \\
(military \& alternative) service, \\
Conscription age, Duration, \\
Population exempt, Availability and \\
restrictions of alternative (civilian) \\
service, Reconciliation of national \\
service with family obligations.
\end{tabular} \\
\hline $\begin{array}{l}8 . \\
\text { Unemployment }\end{array}$ & $\begin{array}{l}\text { Unemployment by age group and sex, Unemployment } \\
\text { by ISCO-88 occupational group and sex, } \\
\text { Unemployment by ISCED education level and sex, } \\
\text { Sectoral unemployment by ISIC activity and sex, } \\
\text { Long-term unemployment by sex, Average time in } \\
\text { unemployment by sex, Public expenditure on } \\
\text { unemployment as \% of GDP, Unemployment by } \\
\text { important ethnic or national groups. }\end{array}$ & $\begin{array}{l}\text { Unemployment by age group } \\
\text { and sex, Unemployment by sex, } \\
\text { Long-term unemployment by } \\
\text { sex. }\end{array}$ & $\begin{array}{l}\text { Description of the unemployment } \\
\text { system, Extent of and reasons for } \\
\text { unemployment in different periods, } \\
\text { Duration of unemployment benefits, } \\
\text { Unemployment benefit calculation } \\
\text { formula, Unemployment benefit } \\
\text { eligibility. }\end{array}$ \\
\hline $\begin{array}{l}\text { 9. Tax/benefit } \\
\text { system }\end{array}$ & Total social expenditure as percentage of GDP. & No regional level indicators. & $\begin{array}{l}\text { General characteristics of the income } \\
\text { tax system, Impact of marriage on } \\
\text { taxes and benefits, Child benefits, } \\
\text { Marginal income tax rate, Regular } \\
\text { VAT rate, Social security contribution } \\
\text { rate. }\end{array}$ \\
\hline $\begin{array}{l}\text { 10. Housing } \\
\text { market and } \\
\text { policies }\end{array}$ & $\begin{array}{l}\text { Public expenditures on housing, Household type by } \\
\text { age group and sex. }\end{array}$ & $\begin{array}{l}\text { Average dwelling size (sqm), } \\
\text { Housing construction by main } \\
\text { housing/ownership type, } \\
\text { Housing stock by main } \\
\text { housing/ownership type. }\end{array}$ & $\begin{array}{l}\text { Housing situation, market and prices, } \\
\text { Housing policies. }\end{array}$ \\
\hline \begin{tabular}{|l}
11. Legal \\
regulations of \\
personal \\
relations \& \\
family \\
responsibilities \\
\end{tabular} & $\begin{array}{l}\text { Percentage of children staying with their mothers after } \\
\text { divorce of parents. }\end{array}$ & No regional level indicators. & $\begin{array}{l}\text { Legal restrictions on abortions, Social } \\
\text { security coverage of abortions, Legal } \\
\text { treatment of same-sex partnerships, } \\
\text { Restrictions on divorce, Legal care } \\
\text { obligations for elderly parents. }\end{array}$ \\
\hline
\end{tabular}


Fig. 1 (Continued).

\begin{tabular}{|c|c|c|c|}
\hline Domains & National level indicators & Regional level indicators & Policy Histories \\
\hline $\begin{array}{l}\text { 12. Education } \\
\text { system }\end{array}$ & $\begin{array}{l}\text { Percentage of students in private schools by ISCED } \\
\text { level, Highest educational attainment (ISCED) by age } \\
\text { and sex, Average school-leaving age by educational } \\
\text { level, Pupil-teacher ratio by school level (ISCED), } \\
\text { Total education expenditures \% of GDP and share of } \\
\text { public expenditures. }\end{array}$ & $\begin{array}{l}\text { Education enrolment rates by } \\
\text { age and sex. }\end{array}$ & $\begin{array}{l}\text { Description of main educational } \\
\text { tracks, Entry age and duration of } \\
\text { compulsory schooling, Years of } \\
\text { common education before the first } \\
\text { important educational differentiation, } \\
\text { School days and total hours per week } \\
\text { by ISCED level, Registration and/or } \\
\text { Tuition Fees and financial support for } \\
\text { students in tertiary education. }\end{array}$ \\
\hline 13. Health & $\begin{array}{l}\text { Healthy life expectancy at birth, Maternal deaths per } \\
100,000 \text { live births, Infant deaths per } 1000 \text { live births, } \\
\text { Healthy life expectancy at age } 60 \text {, Percentage of total } \\
\text { population covered by health insurance, Physicians per } \\
10,000, \text { Hospital beds per } 10,000 \text {, Total health } \\
\text { expenditures as \% of GDP and share of public } \\
\text { expenditures, Health insurance coverage for non-active } \\
\text { population. }\end{array}$ & Life expectancy at birth. & Description of health care system. \\
\hline 14. Elderly care & $\begin{array}{l}\text { Elderly people living in institutions by sex; Elderly by } \\
\text { age group receiving private, formal, or private \& } \\
\text { formal home care by sex; Public expenditures for } \\
\text { elderly care services. }\end{array}$ & No regional level indicators. & $\begin{array}{l}\text { Measures for elderly in need for care, } \\
\text { Pension benefits for family care- } \\
\text { givers, Supportive measures for } \\
\text { working care givers. }\end{array}$ \\
\hline $\begin{array}{l}\text { 15. Political } \\
\text { system }\end{array}$ & $\begin{array}{l}\text { Ruling governmental coalitions on the regional level, } \\
\text { Main political parties. }\end{array}$ & Ruling governmental coalitions. & No policy histories. \\
\hline $\begin{array}{l}\text { 16. Culture \& } \\
\text { values }\end{array}$ & Internet users (per 1000 people). & $\begin{array}{l}\text { Religious, language, and ethnic } \\
\text { composition of the population. }\end{array}$ & No policy histories. \\
\hline
\end{tabular}

\section{Data collection, data preparation, and database development}

\subsection{Up to 2008}

The data collection up to 2008 was conducted in a decentralised manner by national teams of national statistical offices, research institutes, or research departments within statistical offices that were involved in the GGP. It was carried out on the basis of specific guidelines, variable definitions, and table templates provided in spread-sheets by the co-ordination team at the MPIDR (Spielauer 2004b, 2007). The guidelines incorporated the recommendations made in the papers that developed the conceptual framework and content of the database. They included all of the variables and topics illustrated in Fig. 1 and a list of preferred international data sources. The data were checked and published online by the CDB co-ordination team of the MPIDR. The web implementation was realised as a static web application. This made it possible for users to navigate by country and database topic. Users could access and download (in .HML, .XLS, or .CDL) individual tables, which were complemented by variable definitions and links to corresponding tables of other countries (Spielauer 2004b, 2007). As of December 2008, data were available for nine countries: Bulgaria, Canada, Georgia, Hungary, Lithuania, Norway, Poland, Romania, and Russia. 


\subsection{Developments between 2009-2012}

One of the lessons learned from the database implementation process through the end of 2008 was that the focus on decentralised data collection was making it difficult to compile cross-county comparative data. The national data that were collected often did not comply with the variable definition provided by the CDB co-ordination team, which interfered with the goal of making crosscountry comparative data available in the database. Moreover, the collection of data for more than 200 indicators created a substantial workload for the national experts. Database users were also concerned with the functionality of the web application, as it did not allow them to visualise and extract data for multiple countries simultaneously.

Financial support received from the EU 7th Framework Research Programme made it possible to address and overcome these problems. In seeking solutions, the CDB co-ordination team of the MPIDR $^{6}$ established the following objectives:

1. Centralise specific parts of the data collection activities in order to increase the number of indicators that are comparative across countries. The CDB indicators that had become available in international web databases over the previous decade could be collected directly by the central co-ordination team. In addition, the CDB team continued its efforts to harmonise the data that had already been collected.

2. Collaborate with national representatives to increase the number of countries that submit detailed national data to the $\mathrm{CDB}$, and update the time series of the data that had already been collected.

3. Improve the functionality of the database.

\subsubsection{Increasing the number of comparative indicators}

The CDB co-ordination team started off with a comprehensive variable-by-variable comparison of the data that had already been collected for the following: cross-country comparability; completeness of the time series; errors; deviation from the required definitions; and completeness of the data sources, notes, and other documentation necessary to understand the variables, to

\footnotetext{
${ }^{6}$ The co-ordination team was composed by Arianna Caporali (data harmonisation and documentation, review of national data collections), Sebastian Klüsener (relations with national data collectors, concept development for the new web environment, adviser in data harmonisation and documentation), Gerda Neyer (senior scientific advisor), Sandra Krapf (coordination of student assistants), Olga Grigorieva (legal aspects linked to the dissemination of data obtained from national and international sources), and Fred Heiden (programmer).
} 
reconstruct them, and/or to find the proper sources to update them. The screening of each variable was documented (see Appendix A), and a systematic overview was created to facilitate subsequent corrections, updates, and efforts to further improve cross-country comparability.

The main finding that arose from the cross-country variable-by-variable comparison was that clear and detailed guidelines and precise variables definitions were needed to provide the national expert teams with instructions on which data should be collected, and on how to collect the data. The team also found that a metadata documentation of the collected data was essential to ensure comparability and transparency. This issue was of special concern because the CDB team had decided to improve metadata access in the new database environment. Thus, in addition to giving meta-information for each indicator, the new database environment also provides access to metadata for each single data entry. This includes information on the source and quality flags. If, for example, the data provided for some countries or regions deviates from the variable definition, this is documented in the metadata information. A quality flag is also assigned to each indicator. The flag is green for all of the indicators that contain only cross-country comparative data, while it is red for those indicators that contain non-comparative data; the latter are, however, the exception. Moreover, it was necessary to ensure that the regional data complied with the regions used to geocode the place of residence and place of birth of the persons interviewed in the GGS, and with other international regional coding schemes (i.e., NUTS and OECD). This was important because the new web environment was designed to automatically link the extracted regional data with these geocodes.

To ensure the highest levels of availability and comparability over as many countries and as much time as possible, the data compiled by the national experts were contrasted with the data accessible in international databases of supranational organisations (e.g., European Union, World Bank, UNESCO, OECD, WHO) and databases of research consortia (e.g., Human Fertility Database, and Human Mortality Database) (see Appendix B) for each variable in the CDB. In addition, the data were compared with comparative data assembled by UNECE/ PU for inclusion in the $\mathrm{CDB}^{7}$. The inventories of the main international comparative databases (Bisogno 2002; EDACwowe website; Neyer 2003; Saraceno and Keck 2008; Spielauer 2004a; Thévenon 2008) were used as starting points for identifying the relevant databases. This was done for each of the variables included in the CDB. A schematic overview of this comparison was worked out (see Appendix A) to provide some

\footnotetext{
${ }^{7}$ The collection was carried out by Luciano Lavecchia in September 2008.
} 
insight into the extent to which the available international databases provided data for each indicator that were based on the same definitions.

This comparison showed that the CDB offered much more data than other international databases in some areas. For example, the CBD provided rich data at the sub-national regional level, long time series for many indicators (as far back as the 1970s), and extensive coverage of Central and Eastern European countries. However, for certain variables (e.g., in the areas of economy, labour market, and unemployment), the data from the international databases allowed the team to replace incomparable data with comparable data or to complement national data in the CDB with the purpose to provide longer time series. Furthermore, international sources allowed the coordination team to increase the number of variables and countries not yet included in the CDB. Therefore, the team decided to extend the country coverage of the GGP-CDB to all countries in the UNECE region (Europe and Central Asia) and to the GGP countries in North America, Asia, and Oceania. In addition, the team decided to include a set of new variables available in international databases that correspond to the GGS modules and sections. These data were collected ex-ante by the CDB coordination team; the national collectors were then asked to compare and complement these data with data from national sources, and to provide any missing data. For example, the CDB now includes comparative policy indicators from Anne Gauthier's Comparative Family Policy Database that cover all OECD-countries.

Two main sets of improvements came from this work. First, the team decided to further improve the guidelines for data collectors in order to increase the cross-country comparability of the indicators provided in the database. Second, the data harmonisation and preparation process by the CDB coordination team was modified.

\subsubsection{New guidelines for national data collections}

Definitions and references to international sources were revised for each variable (see Appendix C). The collectors are now asked to provide national variable definitions, as well as extensive references and information on national data sources. In order to make the data collection more efficient, variables are identified for which data can be obtained centrally by the CDB team from international sources. These data are included in the data collection sheets that are sent out to the national experts. Depending on the available data, the national collaborators may be asked to check, validate, or complement the data. The new guidelines are expected to substantially reduce the workload of the national experts and to make the process of collecting and providing data more 
efficient in terms of comparability across countries. The new template was presented and approved at the GGP Consortium Board meeting in Paris in March 2011.

\subsubsection{Improved data harmonisation and data preparation}

The data harmonisation and preparation is carried out by the CDB co-ordination team with support provided by student assistants employed at the MPIDR ${ }^{8}$. The decision regarding which variables should be given priority in the harmonisation process is made in close collaboration with the researchers involved in the GGP. A list of indicators of key importance for multi-level analyses using GGS was discussed and approved at the Consortium Board meeting Paris in March 2011. The board decided to focus the harmonisation efforts mostly on demographic and socio-economic indicators, while postponing harmonisation activities for the majority of the policy indicators to a later stage of the project. ${ }^{9}$

The data harmonisation consists of five phases. First, for a given indicator, the CDB team pulls together all of the available data and metadata in a single spread-sheet file. This file includes data and metadata provided by the national teams (when available), as well as data downloaded from the selected international databases. For each source, metadata information on the data and the variable definition are also collected. The student assistants help to organise all of the data in a single table by years (in the rows) and sources (in the columns). This provides a comprehensive overview of all of the available data for each indicator from each country, and makes it possible to compare data from different sources.

Second, the team cross-checks all of the various sources and selects the best combinations. The choice of data sources is determined by the following set of pre-established criteria: compliance with GGP-CDB guidelines and with international standards, comparability across countries, completeness, the spatial and temporal availability of the respective indicators, and the availability of well-documented metadata information and of variable definitions. Two cases can be identified; in both cases, the time series may be the result of combinations of different data sources:

1) For those variables related to the core competencies of the collaborating national institutions and experts (e.g., demographic indicators), national sources provided by CDB national data

\footnotetext{
${ }^{8}$ In alphabetic order: Jana Amtsberg, Maria Asmus, Ingrid-Erika Banciu, Matthias Dettendorfer, Michael Henke, Jonas Richter-Dumke, Mathias Voigt.

${ }^{9}$ This decision was made because several other international research teams were collecting policy data (particularly policies related directly to family and fertility issues). Following discussions with these research teams, the CDB decided to await their work rather than repeating work which was already being carried out by other researchers.
} 
collectors are preferred, assuming they are available and are in compliance with the preestablished set of criteria. If the time series contain gaps, an effort is made to fill them with data from international sources that are comparable with the data provided by national collectors. The same international sources are used to derive data for missing countries. This method was, for example, implemented for demographic variables such as mean age at birth, number of marriages, and mean age at first marriage (see Appendix D).

2) For indicators that are already harmonised and checked for comparability across countries by databases of international organisations and/or research consortia (e.g., macroeconomic indicators and labour market variables) these international sources are preferred. So that the data of international organisations could be included in the CDB, the team obtained formal (legal) permission and authorisation to disseminate the data from these organizations. Permission to disseminate was also sought from the research teams who provided their data for the $\mathrm{CDB} .{ }^{10}$ In order to cover the greatest possible number of countries and years, it is sometimes necessary to combine a number of comparable sources. To ensure data consistency, an effort is made to avoid using different sources across countries for the same years. Visual representations and consistency checks are used in making decisions about what data should be included in the database. National sources provided by $\mathrm{CDB}$ national data collectors are used only for the countries that are missing in international databases, and then only if their data are comparable with the data from other countries, and are in compliance with the pre-established criteria. This has been done for some Central and Eastern European countries. For example, this method has been applied for indicators related to the gross domestic product, the consumer price index, poverty, labour force participation, unemployment, and various public expenditures (e.g., expenditures on health, childcare, education, pensions, family allowances) (see Appendix E).

The third phase of the data harmonisation process consists of organising the metadata information. The metadata linked to each indicator include a definition of the data, a list of all of the national and international sources used to derive the data, and general comments about the sources used and the time series provided. As was mentioned above, the indicators are also marked with quality flags that provide information about the cross-country comparability of the data provided. The meta-

\footnotetext{
${ }^{10}$ The authors wish to thank all of the international organisations and research consortium and all of the GGP national collection teams who have given us permission to disseminate their data.
} 
information linked to each single data entry includes the following: information on the source, usually with a link; the deviation from the general indicator definition, where applicable; and information on the calculation/estimation procedures to derive the given number. Furthermore, for each data entry, specific comments may provide information about any possible break in the series due to revisions of data collections methods and/or changes in national and sub-national regional boundaries.

In the fourth phase of the data harmonisation process, student assistants help to prepare and code all of the collected data and metadata in order to upload it into the new database web environment. Finally, the harmonised time series that have been built are revised following the submission of new data collected by national teams. When applicable, the data in the harmonised data files are replaced with the new data provided by national collectors.

\subsubsection{The new Web interface and database functionality}

The funding received by the EU $7^{\text {th }}$ Framework Research Programme also allowed the coordination team to improve the functionality of the $\mathrm{CDB}$ and to integrate it into the new official webpage of the GGP programme (http://www.ggp-i.org). The new database environment is set up as a dynamic system, based on a relational database (MS SQL Server). The web interface is programmed in PERL using additional technologies (JavaScript, Ajax, and Flash). In contrast to the static system that preceded it, the new system offers a dynamic choice of indicator values across countries, regions, and time, as well as other selection features when available (e.g., age, sex). In addition, the user can choose the dimensions of the output (e.g., to organise the data columns by regions, by time, etc.) (see Appendix F).

As was mentioned above, unlike the majority of existing databases, the CDB provides not only general indicator-wise metadata, but also meta-information for each single data entry. One way the user can access this meta-information is by clicking on the data cell in the output. Another option for accessing the meta-information linked to single data entries is offered to the user in the process of defining the dimensions of the output. Here, the user can choose the "Single value column incl. meta data" output, which displays both the values and the meta-information in a single table. The new database also offers to plot the data. Several dynamic plot options are available, including bar plot, line plot, and pie plot. These plots are interactive, allowing the user to zoom in on specific time periods, or to include or exclude countries and/or regions. 
Another feature that makes the GGP-CDB database different from most other databases is its dynamic geocoding and export function. For contextual data from countries and regions covered in the GGP survey, the user can choose to include an ID column in the output that provides the geocode used in the survey to identify the place of residence of an interviewed person. With this code, the user should find it easy to match the extracted CDB data with the GGP survey data. In addition to the GGP codes, other regional coding schemes, such as NUTS and OECD, are also supported, which allows researchers to match the CDB data with data from other surveys (e.g., the European Social Survey). Data can be exported in different formats (e.g., CSV, XLS, and XML).

\section{Data availability as of January 2013}

In accessing the CDB webpage, the user can choose between two options: the Contextual Database (CDB) and the Contextual Data Collection (CDC). With a few exceptions, the Contextual Database (CDB) contains only harmonised contextual variables. An overview table in Excel format "Overview - Available Indicators per Country" provided on the webpage contains information on data availability by indicators and countries. It also tells the user whether the data are available at the national level only, or also at the regional level. As of January 2013, the database contains 93 indicators covering up to almost 60 countries in Europe, North America, Asia, and Oceania. The time frame reaches as far back as possible (for most indicators, until 1970) and ends with the most recent data obtainable at the time of data preparation. The available indicators are related to the following 10 domains of the CDB: Demography, Economy and Social Aspects, Labour and Employment, Unemployment, Childcare, Education, Health, Pension, Culture, Tax and Benefits.

The Contextual Data Collection (CDC) contains the complete national datasets with more than 200 indicators, which were collected by the national experts in the participating GGP countries. While the CDC national datasets are not always comparative across countries, they are very rich in terms of the national sources used, and they may be very useful in making regional comparisons within countries. They also contain summaries of policy reforms and descriptions of economic and social systems.

As of January 2013, the CDC contains 12 datasets available for download: Austria, Belgium, Bulgaria, Canada, France, Georgia, Germany, Hungary, Lithuania, Norway, Romania, and Russia. 


\section{Conclusion}

This paper provided an overview of the conceptual considerations and recent advances in the implementation of the GGP Contextual Database. Although the database was primarily designed to support multi-level research in demography, it may also be useful to researchers interested in studying macro-level trends. The main characteristics of GGP-CDB are as follows: 1) it offers regional-level data for nearly all its indicators; 2) it includes descriptions of key policy reforms concerning almost all of its domains; 3) it contains harmonised time series comparable both across countries and years for a substantial number of indicators; and 4) it makes available harmonised time series in a dynamic, user-friendly web environment with innovative functionalities, both in terms of metadata documentation and the automatic geocoding of national as well as regional data. The co-existence of all these features in the GGP-CDB makes it a unique support tool for researchers interested in the micro-macro linkages of social structures and processes. It might also serve as a model for the development of contextual databases of other surveys.

In the future, the GGP-CDB will include an update of the indicators that have already been harmonised, as well as a greater number of indicators that are comparable across countries. Efforts will be made to harmonise policy histories. To learn more about how this can be done, the CDB team will examine recent experiences with the establishment of international databases of policy measures, such as the Multilinks Database on Intergenerational Policy Indicators (http://multilinksdatabase.wzb.eu/) and the Population and Policy Database (PPD, http://www.demogr.mpg.de/cgibin/databases/PPD/index.pli). The possibility of deriving aggregate data from GGS individual-level data will also be explored. Eventually, the metadata might be adapted to meet international standards of data documentation, such as the SDMX (Statistical Data and Metadata Exchange, http://www.sdmx.org) (Gregory and Heus 2007). 


\section{References}

Bisogno, E. (2002). UNECE data of possible interest to GGP Contextual Database. In GGP Contextual database group: Activities and conclusions (23-26). Available at http://www.unece.org/fileadmin/DAM/pau/_docs/ggp/2003/GGP_2003_IWG002_BgDocCDBWG. pdf.

EDACwowe website (http://www.edac.eu). European Data Center for Work and Welfare.

Festy, P. (2001). Designing a Macro-Context for the G\&G Individual Data. Paper presented at the First Meeting of the Informal Working Group of the Generations and Gender Programme, Budapest, Hungary, 24-25 September 2001. Available from the author: festy@ined.fr

Festy P. (2002). From GGS to GGP; from micro- to macro- via meso- levels. Variables in the survey [GGS] and in the contextual database [CDB]. In GGP Contextual database group: Activities and conclusions (18-21). Available at http://www.unece.org/fileadmin/DAM/pau/ docs/ggp/2003/GGP 2003 IWG002 BgDocCDBWG. pdf.

Festy, P. (2004). GGP Contextual database group: first discussions, first conclusions. Available from the author: festy@ined.fr

Gregory, A., Heus, P. (2007). DDI and SDMX: Complementary, not Competing, Standards. Open Data Foundation Papers.

Available at: http://www.opendatafoundation.org/papers/DDI_and_SDMX.pdf.

Goldscheider, F. K. (2000). Realizing the Potential of FFS1 with Contextual Data, Presentation at the FFS Flagship Conference 2000. Available at http://www.unece.org/fileadmin/DAM/pau/ docs/ffs/FFS 2000 FFConf SolicGoldscheider.pdf

Macura, M. (2002). Executive Summary. The Generations and Gender Programme: A Study of the Dynamics of Families and family Relationships. Available at http://www.unece.org/fileadmin/DAM/pau/_docs/ggp/2003/GGP_2003_IWG002_BgDocProgrExe cSumm.pdf.

Neyer G. (2002). Gender and Generations Dimensions in Welfare-State Policies. In GGP Contextual database group: Activities and conclusions (5-10). Available at 
http://www.unece.org/fileadmin/DAM/pau/_docs/ggp/2003/GGP_2003_IWG002_BgDocCDBWG. pdf.

Neyer, G. (2003). Gender and Generations Dimensions in Welfare-State Policies, MPIDR Working Paper WP 2003-022. Rostock: Max Planck Institute for Demographic Research. Available at http://www.demogr.mpg.de/papers/working/wp-2003-022.pdf.

Racioppi, F. and G. Rivellini (2002). The Contextual Dimension in GGP: Some Methodological Issues about Data Collection and Sampling Procedures In GGP Contextual database group: Activities and conclusions (11-17). Available at http://www.unece.org/fileadmin/DAM/pau/_docs/ggp/2003/GGP_2003_IWG002_BgDocCDBWG. pdf.

Saraceno, C. and W. Keck. (2008). The Institutional Framework of Intergenerational Family Obligations in Europe: A Conceptual and Methodological Overview. Wissenschaftszentrum Berlin für Sozialforschung (WZB). First deliverable of work package 1 of the multilinks project funded by the European Commission under the seventh framework programme. Available at: http://multilinksdatabase.wzb.eu/pdf/conceptual-report.pdf

Spielauer, M. (2004a). The Contextual Database of the Generations and Gender Program:

Overview, Conceptual Framework and the Link to the Generations and Gender Survey, MPIDR Working Paper WP 2004-014. Rostock: Max Planck Institute for Demographic Research. Available at http://www.demogr.mpg.de/papers/working/wp-2004-014.pdf.

Spielauer, M. (2004b). The Generations and Gender Contextual Database: Concepts and Content, MPIDR Working Paper WP 2004-026. Rostock: Max Planck Institute for Demographic Research. Available at http://www.demogr.mpg.de/papers/working/wp-2004-026.pdf.

Spielauer, M. (2006). The Contextual Database of the Generations and Gender Program. MPIDR Working Paper WP 2006-030. Available at: http://www.demogr.mpg.de/papers/working/wp-2006030.pdf.

Spielauer, M. (2007). PART TWO - The Contextual Database of the Generations and Gender Programme. In United Nations, Generations and Gender Programme - Concepts and Guidelines (33-44). New York/ Geneva: United Nations Publications. Available at: http://www.unece.org/fileadmin/DAM/pau/_docs/ggp/2008/GGP_2008_Publ.pdf. 
Thévenon O. (2008). Family Policy in Europe: Available databases and Initial Comparisons. Vienna Yearbook of Population Research. 2008: 165-177.

Available at: http://hw.oeaw.ac.at/0xc1aa500d_0x001c9ea5.pdf.

United Nations (2000). Generations and Gender Programme: Exploring Future Research and Data Collection Options. New York/ Geneva: United Nations Publications.

United Nations (2005). Generations and Gender Programme: Survey Instruments. New York/

Geneva: United Nations Publications. Availale at:

http://www.unece.org/pau/pub/ggp_survey_instruments.html.

United Nations (2007). Generations and Gender Programme: Concepts and Guidelines. New York/ Geneva: United Nations Publications. Available at:

http://www.unece.org/pau/pub/ggp_concepts_guidelines.html.

United Nations (2008). What UNECE does for you...UNECE works on the generations and gender programme. New York/ Geneva: United Nations Publications. Available at; http://www.unece.org/index.php?id=17623.

United Nations (2009). How generations and gender shape demographic change. Towards Policies Based on Better Knowledge. Conference Proceedings. New York/ Geneva: United Nations Publications. Available at: http://www.unece.org/pau/pub/ggp_conference_2009.html.

Vikat et al. (2007). Generations and Gender Survey (GGS): Towards a better understanding of relationships and processes in the life course. Demographic Research 17 (14): 389-440. Available at http://www.demographicresearch.org. 


\section{Appendix A: An extract from the variable-by-variable overview of data in the Contextual Database and other international databases - indicator "Gini Coefficient"}

The report was finished at the end of December 2008. The overview therefore refers to data availability up to that time.

\section{Gini Coefficient}

- General requirements for the GGP national data collectors (following the guidelines provided in the CDB template): The collectors are asked to provide data at the national level since 1970, and on alternative income concepts if available. The World Bank and WIDER (World Income Inequality Database) are indicated as the databases that provide comparable data on this indicator, with reference to different income concepts.

- Missing data: No data are available for Poland.

- Overview of available data and sources in the CDB: Bulgaria: 1989-2003; only with reference to one income concept which is not defined in the note; Bulgarian Statistical Office. Canada: 19802004; calculated with after-tax income; Statistics Canada, CANSIM (Table 202-0705). Georgia: 1996-2006; no definition of the income concept; Departments for Statistics of Georgia. Hungary: 1987, 1992, 1996, 2000, 2003; no definition of the income concept; Jövedelemeloszlás. 2005 Századvég - ARTT, Tóth István György. Lithuania: 2000-2005; the income concept chosen for 2005 is the equalised household monetary income after transfers; the income concept chosen for 2000-2004 is the equalised household income after transfers in cash and income in kind from employment; Statistics Lithuania. Norway: no definition of the income concept; Luxembourg Income Study: 1) LIS key figures - Table 1: Income Inequality Measures for the years 1979, 1986, 1991, 1995, 2000; 2) Statistics Norway: Økonomie og levekår for ulike grupper, 2005 Rapporter 2006/3 for the years 1990-2004. Romania: 1989, 1993-2003; no definition of the income concept; Eurostat; for 2003 the data source is CASPIS. Russia: 1991-2003; no definition of the income concept; Federal State Statistic Service of Russia.

- Evaluation of comparability/suggestions on how to ameliorate data: The income concept used in the calculation of the coefficient is not known for all of the countries. This information is necessary for determining whether the data are comparable. Furthermore, the template required countries to provide data with reference to a different concept of income. The team may aim to provide the coefficient with reference to gross and net income concept. In the guidelines, it is necessary to explicitly require countries to provide information concerning the income concept applied.

- International databases that provide comparable data:

- UNECE statistics: Data from Eurostat, 1995-2006. Data not available for Canada, Georgia, Russia.

- Eurostat Data explorer: Data from SILC, 2000-2008. Data not available for Canada, Georgia, Russia.

- WIDER database: Provides Gini coefficients with reference to different concepts of income and consumption for all of the countries in the CDB.

- The World Bank: Gini index for all of the countries in the CDB.

- OECD database: OECD countries only (no Bulgaria, Georgia, Lithuania, Romania). The OECD provides the Gini coefficient based on the equalised household market income in two variants: before taxes and transfers and after taxes and transfers. The data are available in rough five-year intervals.

- A list of relevant sources is available here:

http://www.edacwowe.eu/en/frmSearch?v_search=Gini+Coefficient. 


\section{Appendix B: Main international comparative sources examined.}

- International databases of national and supranational organisations (in alphabetical order):

- CIA (Central Intelligent Agency) - The World Factbook: https://www.cia.gov/library/publications/the-world-factbook/

- COE (Council of Europe) - Recent Demographic Trends: http://www.coe.int/t/e/social_cohesion/population/demographic_year_book/

- EDACO (European Data Center for Work and Welfare): http://www.edac.eu/fswjpb/spits.edac.frmIndex

- European Commission - Social protection systems MISSOC database: http://ec.europa.eu/employment social/missoc/db/public/compareTables.do?lang=en

- European Observatory on Health Systems and Policies - Health System Reviews (HiTs): http://www.euro.who.int/en/who-we-are/partners/observatory/health-systems-in-transitionhit-series

- EURYDICE - Information Network for Education: http://eacea.ec.europa.eu/education/eurydice/eurybase_en.php

- Eurostat - data explorer: http://epp.eurostat.ec.europa.eu

- HDR (Human Development Report): http://hdr.undp.org/en/statistics/

- ILO (International Labour Organisation) Databases: http://www.ilo.org/global/statisticsand-databases/lang--en/index.htm

- Nation Master: http://www.nationmaster.com/index.php

- OECD - OECD. Stat: http://stats.oecd.org/index.aspx

- OECD - Family Database: http://www.oecd.org/document/4/0,3343,en_2649_34819_37836996_1_1_1_1,00.html

- OECD - Social Expenditure Database (SOCX): http://www.oecd.org/social/socialpoliciesanddata/socialexpendituredatabasesocx.htm

- OECD - Tax Database: http://www.oecd.org/document/60/0,3343, en $264934533 \quad 1942460 \quad 1 \quad 1 \quad 11$ 1,00.html

- U.S. Social Security Administration - Social Security Programs Throughout the World: http://www.socialsecurity.gov/policy/docs/progdesc/ssptw/

- TransMonEE (Transformative Monitoring for Enhanced Equity): http://www.transmonee.org

- United Nations (UN) Statistical Division - UNdata explorer: http://data.un.org/Explorer.aspx

- United Nations Economic Commission for Europe (UNECE) Statistical Database: http://w3.unece.org/pxweb/Dialog/.

- UNO WIDER - United Nations University World Institute for Development Economics Research: http://www.wider.unu.edu/research/Database/en_GB/database/

- UNESCO Institute for Statistics: http://stats.uis.unesco.org

- U.S. Census Bureau - International Data Base (IDB): http://www.census.gov/ipc/www/idb/informationGateway.php

- The World Bank: http://databank.worldbank.org 
- WHO HFA-DB (World Health Organisation - European health for all database): http://data.euro.who.int/hfadb/

- WHO WHOSIS (World Health Organisation - Statistical Information System): http://apps.who.int/whosis/data

- International databases of research consortia (in alphabetical order):

- CESifo (Centre for Economic Studies - Ifo institute) DICE - Database for Institutional Comparisons in Europe: http://www.cesifo-group.de/ifoHome/facts/DICE.html

- Clearinghouse on International Developments in Child, Youth and Family Policies at Columbia University: http://www.childpolicyintl.org/

- Comparative Family Policy Database: http://www.demogr.mpg.de/cgibin/databases/FamPolDB/index.plx

- GESIS - Leibniz Institute for the Social Sciences - EUSI European System of Social Indicators: http://www.gesis.org/en/services/data/social-indicators/eusi/

- Human Fertility Database: http://www.humanfertility.org/cgi-bin/main.php

- Human Mortality Database: http://www.mortality.org/

- Ined - Database on Developed Countries : http://www.ined.fr/en/pop_figures/developed_countries_database

- International Network on Leave Policy and Research - The annual reviews: http://www.leavenetwork.org/archive 2005 2009/annual reviews/

- LIS (Luxembourg Income Study) Databases : http://www.lisdatacenter.org/resources/other-databases/

- Population and Policy Database: http://www.demogr.mpg.de/cgibin/databases/PPD/index.pli

- SCIP (Social Citizenship Indicator Program) at SOFI (Swedish Institute for Social Research)

- WRI (World Resources Institute) Earth Trends: http://www.wri.org/project/earthtrends/ 
Appendix C: Extract from the new guidelines for national data collectors

\begin{tabular}{|c|c|c|c|c|c|c|c|c|c|c|c|c|c|c|}
\hline $\begin{array}{l}\text { Var } \\
\text { nr }\end{array}$ & Domain & Template & $\begin{array}{l}\text { Varname } \\
\text { _short }\end{array}$ & $\begin{array}{l}\text { Varname } \\
\text { full }\end{array}$ & Definition & Def_link & $\begin{array}{l}\text { Reg } \\
\text { dim }\end{array}$ & $\begin{array}{l}\text { Age } \\
\text { dim }\end{array}$ & $\begin{array}{l}\text { Who } \\
\text { dim }\end{array}$ & $\begin{array}{l}\text { Time } \\
\text { dim }\end{array}$ & $\begin{array}{l}\text { Cat } \\
\text { dim }\end{array}$ & Notes & $\begin{array}{l}\text { Collector } \\
\text { (NT= National } \\
\text { Team; CCT }= \\
\text { Central Co- } \\
\text { ordination } \\
\text { Team) }\end{array}$ & $\begin{array}{l}\text { Var_nr in } \\
\text { v1.00 CDB_ } \\
\text { Templates }\end{array}$ \\
\hline 0117a & Demography & 2 & NM - reg & $\begin{array}{l}\text { Number of } \\
\text { marriages } \\
\text { - regional }\end{array}$ & $\begin{array}{l}\text { A marriage is the act, ceremony, or } \\
\text { process by which the legal } \\
\text { relationship of a husband and wife } \\
\text { is constituted. The legality of the } \\
\text { union may be established by civil, } \\
\text { religious, or other means as } \\
\text { recognised by the laws of each } \\
\text { country. }\end{array}$ & $\begin{array}{l}\text { CODED- The } \\
\text { Eurostat Concepts } \\
\text { and Definitions } \\
\text { database } \\
\text { (http://ec.europa.eu/ } \\
\text { eurostat/ramon) }\end{array}$ & REG & -- & -- & $2000+$ & $\begin{array}{l}\text { [value- } \\
\text { number] }\end{array}$ & \begin{tabular}{|l|} 
To our knowledge, no \\
international database \\
provides this variable. \\
Please provide data \\
from national statistical \\
offices. Please number \\
the regions as coded in \\
the GGS. Please \\
indicate whether the \\
marriages refer only to \\
the resident populations \\
or to all of the \\
marriages celebrated \\
during the reference \\
year. \\
\end{tabular} & NT & $0117 \mathrm{a}$ \\
\hline 0203a & $\begin{array}{l}\text { Economy } \\
\text { and Social } \\
\text { Aspects }\end{array}$ & 1 & GC WB & $\begin{array}{l}\text { Gini } \\
\text { coefficient } \\
\text { (World } \\
\text { Bank) }\end{array}$ & $\begin{array}{l}\text { The Gini coefficient measures the } \\
\text { extent to which the distribution of } \\
\text { income (or, in some cases, } \\
\text { consumption expenditure) among } \\
\text { individuals or households within } \\
\text { an economy deviates from a } \\
\text { perfectly equal distribution. A } \\
\text { Lorenz curve plots the cumulative } \\
\text { percentages of total income } \\
\text { received against the cumulative } \\
\text { number of recipients, starting with } \\
\text { the poorest individual or } \\
\text { household. The Gini coefficient } \\
\text { measures the area between the } \\
\text { Lorenz curve and a hypothetical } \\
\text { line of absolute equality. Thus a } \\
\text { Gini coefficient of } 0 \text { represents } \\
\text { perfect equality, while an index of } \\
1 \text { implies perfect inequality. The } \\
\text { World Bank provides data on an } \\
\text { annual basis. }\end{array}$ & $\begin{array}{l}\text { The World Bank: } \\
\text { World Development } \\
\text { Indicators (WDI) \& } \\
\text { Global } \\
\text { Development } \\
\text { Finance (GDF) } \\
\text { dataset } \\
\text { (http://data.worldba } \\
\text { nk.org/) }\end{array}$ & NAT & -- & -- & {$[1]$} & $\begin{array}{l}\text { [value- } \\
\text { number] }\end{array}$ & $\begin{array}{l}\text { The main international } \\
\text { source that provides this } \\
\text { variable is the World } \\
\text { Bank. Please specify } \\
\text { the income concept } \\
\text { applied (equivalence } \\
\text { scales, gross/net income } \\
\text { etc.) in case of data } \\
\text { from national statistical } \\
\text { institutes. }\end{array}$ & CCT & 203 \\
\hline
\end{tabular}


This update (1.10) of the previous version of the guidelines (v1.00 CDB_ Templates) includes two new columns: 1) "Collector (NT= National Team; CCT= Central Co-ordination Team)"; and 2)"Var_nr in v1.00 CDB_ Templates". The first of these new columns identifies whether the indicator can be provided by the co-ordination team at the MPIDR, or whether the national collectors should collect these data. For example, since the indicator 0117 a "Number of marriages - regional" does not appear to be available in any international database, the national collectors are asked to provide this figure from the national statistical offices. The national experts are provided with specific guidelines about the data required in the columns "Definition" and "Note". Meanwhile, the indicator 0203 "Gini Coefficient (World bank)" is collected centrally by the team at the MPIDR from the World Bank database. However, if the indicator is not available in the World Bank database for a country, the national collectors of that country will be required to provide comparable data and the corresponding metadata that may allow the team to include this country in the internationally comparable data series (see column "Note").

The second of the new columns indicates the corresponding indicator number in the old templates. In the current templates, new indicators have been introduced, and some indicators that were in the old templates have been moved to a different domain. 
Appendix D: Combination of national sources with international sources - indicator "Mean Age at Birth", Lithuania

(Extensive names of the sources are indicated in the note no. 12, page 27)

\begin{tabular}{|c|c|c|c|c|c|c|c|c|}
\hline Year & Human Fertility database & Eurostat & Eurostat - national Institutes & GESIS-EUSI & COE (2005) & COE (2006) & GGP-CDB & BiB - Germany \\
\hline 1960 & & & & & 29.4 & 29.4 & & \\
\hline 1961 & & & & & & 29.1 & & \\
\hline 1962 & & & & & & 29.2 & & \\
\hline 1963 & & & & & & 29.1 & & \\
\hline 1964 & & & & & & 29.2 & & \\
\hline 1965 & & & & & 28.8 & 28.8 & & \\
\hline 1966 & & & & & & 28.7 & & \\
\hline 1967 & & & & & & 28.4 & & \\
\hline 1968 & & & & & & 28.2 & & \\
\hline 1969 & & & & & & 27.9 & & \\
\hline 1970 & & 27.8 & & & 27.8 & 27.8 & 27.8 & \\
\hline 1971 & & 27.7 & & & & 27.7 & 27.7 & \\
\hline 1972 & & 27.6 & & & & 27.6 & 27.6 & \\
\hline 1973 & & 27.6 & & & & 27.6 & 27.6 & \\
\hline 1974 & & 27.4 & & & & 27.4 & 27.4 & \\
\hline 1975 & & 27.3 & & & 27.3 & 27.3 & 27.3 & \\
\hline 1976 & & 27.3 & & & & 27.3 & 27.3 & \\
\hline 1977 & & 27.1 & & & & 27.1 & 27.1 & \\
\hline 1978 & & 27.0 & & & & 27.0 & 27.0 & \\
\hline 1979 & & 26.9 & & & & 26.9 & 26.9 & \\
\hline 1980 & & 26.7 & & 26.7 & 26.7 & 26.7 & 26.7 & \\
\hline 1981 & & 27.1 & & & & 27.1 & 27.1 & \\
\hline 1982 & & 27.2 & & & & 27.1 & 27.2 & \\
\hline 1983 & & 27.2 & & & & 27.2 & 27.2 & \\
\hline 1984 & & 27.1 & & & & 27.1 & 27.1 & \\
\hline 1985 & & 26.8 & & 26.8 & 26.8 & 26.8 & 26.8 & \\
\hline 1986 & & 26.9 & & & & 26.9 & 26.9 & \\
\hline 1987 & & 26.8 & & & & 26.8 & 26.8 & \\
\hline 1988 & & 26.2 & & & & 26.2 & 26.2 & \\
\hline 1989 & & 25.9 & & & & 25.9 & 25.9 & \\
\hline 1990 & & 25.9 & & 25.9 & 25.9 & 25.9 & 25.9 & \\
\hline 1991 & & 25.7 & & & & 25.7 & 25.7 & \\
\hline 1992 & & 25.6 & & & & 25.6 & 25.6 & \\
\hline 1993 & & 25.7 & & 25.7 & & 25.6 & 25.7 & \\
\hline 1994 & & 25.5 & & 25.5 & & 25.5 & 25.5 & \\
\hline 1995 & & 25.6 & & 25.6 & 25.6 & 25.6 & 25.6 & \\
\hline 1996 & & 25.8 & & 25.8 & & 25.7 & 25.8 & \\
\hline 1997 & & 26.0 & & 26.0 & & 25.9 & 26.0 & \\
\hline 1998 & & 26.3 & & 26.3 & & 26.2 & 26.3 & \\
\hline 1999 & & 26.5 & & 26.4 & & 26.4 & 26.5 & \\
\hline 2000 & & 26.6 & & 26.6 & 26.6 & 26.6 & 26.6 & \\
\hline 2001 & & 26.9 & & 27.2 & & 26.8 & 26.9 & \\
\hline 2002 & & 26.9 & & 26.9 & 26.9 & 26.9 & 26.9 & \\
\hline 2003 & & 27.1 & & 27.1 & 27.1 & 27.1 & 27.1 & \\
\hline 2004 & & 27.4 & & 27.4 & & 27.4 & 27.4 & \\
\hline 2005 & & 27.6 & & 27.6 & & & 27.6 & \\
\hline 2006 & & 27.7 & & 27.7 & & & & \\
\hline 2007 & & 27.9 & 28.0 & & & & & \\
\hline 2008 & & 28.2 & 28.2 & & & & & \\
\hline
\end{tabular}


For indicator 0107a, "Mean Age at Birth" (at the national level), all of the sources indicated in grey in the header of the table were selected ${ }^{11}$. For Lithuania, the data highlighted in green were combined. The data produced by Statistics Lithuania and provided to the CDB co-ordination team by the CDB national team were chosen. The missing years were filled in with data taken from the Eurostat Statistics Database (available at http://epp.eurostat.ec.europa.eu/) and data collections provided by the Council of Europe (COE. Recent demographic developments in Europe 2005. Council of Europe Publishing. 2006. Data on CD-Rom.) which were comparable to the data provided by the CDB national team. The selection was done with the data available to the CDB co-ordination team as of September 2010.

11 In total, the following sources were considered: The Human Fertility Database (http://www.humanfertility.org/cgibin/main.php), Eurostat - data explorer (http://epp.eurostat.ec.europa.eu), GESIS - Leibniz Institute for the Social Sciences EUSI European System of Social Indicators (http://www.gesis.org/en/services/data/social-indicators/eusi/), COE (Council of Europe) - Recent Demographic Trends (http://www.coe.int/t/e/social_cohesion/population/demographic_year_book/), Council of Europe. Recent demographic developments in Europe 2005. Council of Europe Publishing. 2006. Data on CD-Rom, Statistics Lithuania (http://www.stat.gov.lt/en/), BiB - Federal Institute for Population Research (http://www.bibdemografie.de/EN/Home/home_node.html). 
Appendix E: Combination of international sources with other international sources - indicator "Labour Force Participation", France

(Extensive names of the sources are indicated in the note no. 13, page 29)

\begin{tabular}{|c|c|c|c|c|c|c|c|c|c|c|c|c|c|c|c|c|c|c|}
\hline \multirow[b]{2}{*}{ Year } & \multicolumn{3}{|c|}{$\begin{array}{l}\text { GGP-CDB data } \\
\text { (Insee) }\end{array}$} & \multicolumn{3}{|c|}{$\begin{array}{l}\text { UNECE-PU data } \\
\text { (OECD) }\end{array}$} & \multicolumn{3}{|c|}{ ILO Laborista } & \multicolumn{3}{|c|}{ ILO KILM } & \multicolumn{3}{|c|}{ Eurostat Adjusted } & \multicolumn{3}{|c|}{ OECD } \\
\hline & $\mathrm{F}$ & M & TOT & $\mathrm{F}$ & M & TOT & $\mathrm{F}$ & $M$ & TOT & $\mathrm{F}$ & $\mathrm{M}$ & TOT & $\mathrm{F}$ & $\mathrm{M}$ & TOT & $\mathrm{F}$ & $M$ & TOT \\
\hline 1968 & & & & & & & & & & & & & & & & 47.0 & 84.4 & 65.5 \\
\hline 1969 & & & & & & & & & & & & & & & & 47.4 & 83.9 & 65.5 \\
\hline 1970 & & & & & & & & & & & & & & & & 47.6 & 83.6 & 65.5 \\
\hline 1971 & & & & & & & & & & & & & & & & 47.6 & 83.6 & 65.5 \\
\hline 1972 & & & & & & & & & & & & & & & & 48.6 & 83.5 & 66.0 \\
\hline 1973 & & & & & & & & & & & & & & & & 49.4 & 83.4 & 66.4 \\
\hline 1974 & & & & & & & & & & & & & & & & 50.3 & 83.1 & 66.7 \\
\hline 1975 & 53.3 & 83.9 & 68.6 & & & & & & & & & & & & & 51.5 & 82.5 & 67.0 \\
\hline 1976 & 54.3 & 83.6 & 68.9 & & & & & & & & & & & & & 52.5 & 82.2 & 67.3 \\
\hline 1977 & 55.5 & 83.5 & 69.4 & & & & & & & & & & & & & 53.6 & 82.1 & 67.8 \\
\hline 1978 & 55.4 & 83.0 & 69.2 & & & & & & & & & & & & & 53.6 & 81.2 & 67.4 \\
\hline 1979 & 56.6 & 83.2 & 69.9 & & & & & & & & & & & & & 54.8 & 81.8 & 68.3 \\
\hline 1980 & 56.9 & 82.9 & 69.9 & & & & & & & 55.2 & 81.7 & 68.5 & & & & 55.1 & 81.5 & 68.3 \\
\hline 1981 & 56.9 & 81.8 & 69.3 & & & & 43.2 & 68.8 & 55.6 & 55.4 & 80.8 & 68.1 & & & & 55.1 & 80.4 & 67.7 \\
\hline 1982 & 57.1 & 81.0 & 69.0 & & & & 43.8 & 68.4 & 55.6 & 55.6 & 80.1 & 67.9 & & & & 55.3 & 79.6 & 67.4 \\
\hline 1983 & 56.9 & 79.8 & 68.3 & & & & 44.1 & 67.5 & 55.4 & 56.3 & 80.0 & 68.2 & & & & 55.1 & 78.5 & 66.7 \\
\hline 1984 & 57.1 & 78.6 & 67.8 & & & & 44.6 & 66.8 & 55.3 & 56.5 & 78.7 & 67.6 & & & & 55.3 & 77.3 & 66.2 \\
\hline 1985 & 57.4 & 78.6 & 67.9 & & & & 44.7 & 66.1 & 55 & 56.5 & 78.2 & 67.3 & & & & 55.6 & 77.3 & 66.4 \\
\hline 1986 & 58.2 & 78.2 & 68.1 & & & & 44.9 & 65.5 & 54.8 & 57.3 & 77.9 & 67.6 & & & & 56.4 & 76.9 & 66.6 \\
\hline 1987 & 58.3 & 77.7 & 67.9 & & & & 45.2 & 64.9 & 54.7 & 57.2 & 77.3 & 67.2 & & & & 56.5 & 76.3 & 66.3 \\
\hline 1988 & 58.2 & 76.9 & 67.5 & & & & 45.2 & 64.4 & 54.4 & 57.3 & 76.5 & 66.9 & & & & 56.4 & 75.6 & 65.9 \\
\hline 1989 & 58.6 & 76.8 & 67.6 & & & & 45.4 & 64.2 & 54.4 & 57.5 & 76.3 & 66.9 & & & & 56.9 & 75.4 & 66.1 \\
\hline 1990 & 58.9 & 76.3 & 67.6 & & & & 45.5 & 64 & 54.4 & 57.7 & 75.8 & 66.8 & & & & 57.2 & 75.0 & 66.0 \\
\hline 1991 & 59.3 & 75.9 & 67.5 & & & & 45.9 & 63.9 & 54.6 & 58.1 & 74.8 & 66.4 & & & & 57.5 & 74.6 & 66.0 \\
\hline 1992 & 60.0 & 75.8 & 67.8 & 51.40 & 68.70 & 59.90 & 46.2 & 63.1 & 54.3 & 58.7 & 74.9 & 66.8 & 59.2 & 75.3 & 67.1 & 58.2 & 74.6 & 66.3 \\
\hline 1993 & 60.7 & 75.5 & 68.0 & 51.50 & 67.30 & 59.30 & 46.4 & 62.5 & 54.1 & 59.4 & 74.6 & 67.0 & 59.8 & 75.0 & 67.3 & 59.0 & 74.2 & 66.6 \\
\hline 1994 & 61.0 & 75.3 & 68.1 & 51.60 & 66.80 & 59.10 & 46.8 & 62.2 & 54.2 & 59.8 & 74.4 & 67.1 & 60.3 & 74.9 & 67.5 & 59.3 & 74.1 & 66.6 \\
\hline 1995 & 61.5 & 75.2 & 68.3 & 52.10 & 67.20 & 59.50 & 48.7 & 63.4 & 55.8 & 60.5 & 74.3 & 67.4 & 60.8 & 75.0 & 67.8 & 59.9 & 74.0 & 66.9 \\
\hline 1996 & 62.1 & 75.7 & 68.8 & 52.20 & 67.00 & 59.50 & 49 & 63.7 & 56.1 & 61.2 & 75.0 & 68.0 & 61.1 & 75.2 & 68.1 & 60.4 & 74.5 & 67.4 \\
\hline 1997 & 61.8 & 75.5 & 68.6 & 52.40 & 66.90 & 59.60 & 48.6 & 63.3 & 55.7 & 60.9 & 74.9 & 67.8 & 61.2 & 75.1 & 68.1 & 60.2 & 74.3 & 67.2 \\
\hline 1998 & 62.4 & 75.3 & 68.8 & 53.10 & 67.40 & 60.20 & 49 & 63 & 55.7 & 61.4 & 74.8 & 68.1 & 61.9 & 75.2 & 68.4 & 60.8 & 74.1 & 67.4 \\
\hline 1999 & 63.0 & 75.5 & 69.2 & 54.00 & 68.00 & 60.90 & 49.2 & 63 & 55.8 & 62.1 & 75.1 & 68.6 & 62.3 & 75.3 & 68.7 & 61.4 & 74.4 & 67.8 \\
\hline 2000 & 63.3 & 75.6 & 69.4 & 55.20 & 69.20 & 62.10 & 49.5 & 63 & 56 & 62.3 & 75.0 & 68.6 & 62.4 & 75.2 & 68.7 & 61.7 & 74.4 & 68.0 \\
\hline 2001 & 63.4 & 75.5 & 69.4 & 56.00 & 69.70 & 62.80 & 49.6 & 62.9 & 56 & 62.0 & 74.8 & 68.4 & 62.4 & 75.2 & 68.7 & 61.8 & 74.3 & 68.0 \\
\hline 2002 & 63.7 & 75.7 & 69.6 & 56.70 & 69.50 & 63.00 & 49.9 & 63 & 56.2 & 62.3 & 75.2 & 68.7 & 63.0 & 75.5 & 69.1 & 62.1 & 74.5 & 68.3 \\
\hline 2003 & 64.2 & 75.3 & 69.7 & 58.20 & 69.90 & 64.00 & 50.1 & 62.6 & 56.1 & 64.2 & 75.2 & 69.7 & 64.3 & 75.7 & 69.9 & 63.7 & 74.8 & 69.2 \\
\hline 2004 & 64.4 & 75.2 & 69.8 & 58.20 & 69.40 & 63.70 & 50.3 & 62.4 & 56.1 & 64.2 & 75.5 & 69.8 & 64.6 & 75.5 & 70.0 & 64.0 & 74.7 & 69.3 \\
\hline 2005 & 64.6 & 74.9 & 69.6 & 58.50 & 69.30 & 63.90 & 50.6 & 62.3 & 56.2 & 64.8 & 75.3 & 70.0 & 64.8 & 75.3 & 70.0 & 64.3 & 74.6 & 69.4 \\
\hline 2006 & 64.7 & 74.6 & 69.6 & 58.80 & 69.00 & 63.80 & & & & 65.0 & 75.1 & 70.0 & 64.9 & 75.0 & 69.9 & 64.5 & 74.4 & 69.4 \\
\hline 2007 & 65.1 & 74.4 & 69.7 & 60.00 & 69.30 & 64.60 & & & & 65.5 & 74.9 & 70.1 & 65.3 & 74.8 & 70.0 & 65.0 & 74.2 & 69.5 \\
\hline 2008 & 65.5 & 74.6 & 70.0 & & & & & & & 65.8 & 74.9 & 70.3 & 65.6 & 74.8 & 70.1 & 65.2 & 74.3 & 69.7 \\
\hline
\end{tabular}


For the indicator 0301, "Labour Force Participation rate by sex" (at the national level), for all of the countries the source indicated in grey in the header of the table was selected. The database ILO-KILM (Key Indicators of the Labor Market) maintained by the International Labour Organisation (available at http://www.ilo.org/empelm/what/WCMS 114240/lang--en/index.htm) was selected as the main source, because it was the richest source in terms of number of countries and years covered which also provided data comparable across countries. This choice was further determined by the fact that this source also offered well-documented metadata on data processing and adjustment procedures. For the OECD countries, such as for France, which is shown in the example ${ }^{12}$, the missing years 1968-1979 were filled with data from the OECD Databases (available at http://stats.oecd.org/).

${ }^{12}$ For France, in addition to ILO-KILM and OECD, the following sources were considered:

1) Insee - Institut national de la statistique et des études économiques (http://www.insee.fr/fr/); this source was provided by the national collector.

2) UNECE-PU data; data assembled by UNECE/ PU in September 2008 and made available, as part of the GGP, for inclusion in the CDB.

3) ILO Laborista (http://laborsta.ilo.org/).

4) Eurostat - European Labour Force Survey, adjusted series (http://epp.eurostat.ec.europa.eu). 


\section{\begin{tabular}{|l|l|l|l|l|l|}
\hline Home & About & Data & Bibliography & Project & Materials \\
\hline
\end{tabular}}

CDB Home | CDB Data | Demography | Total fertility rate

Generations and Gender Programme - Contextual Database

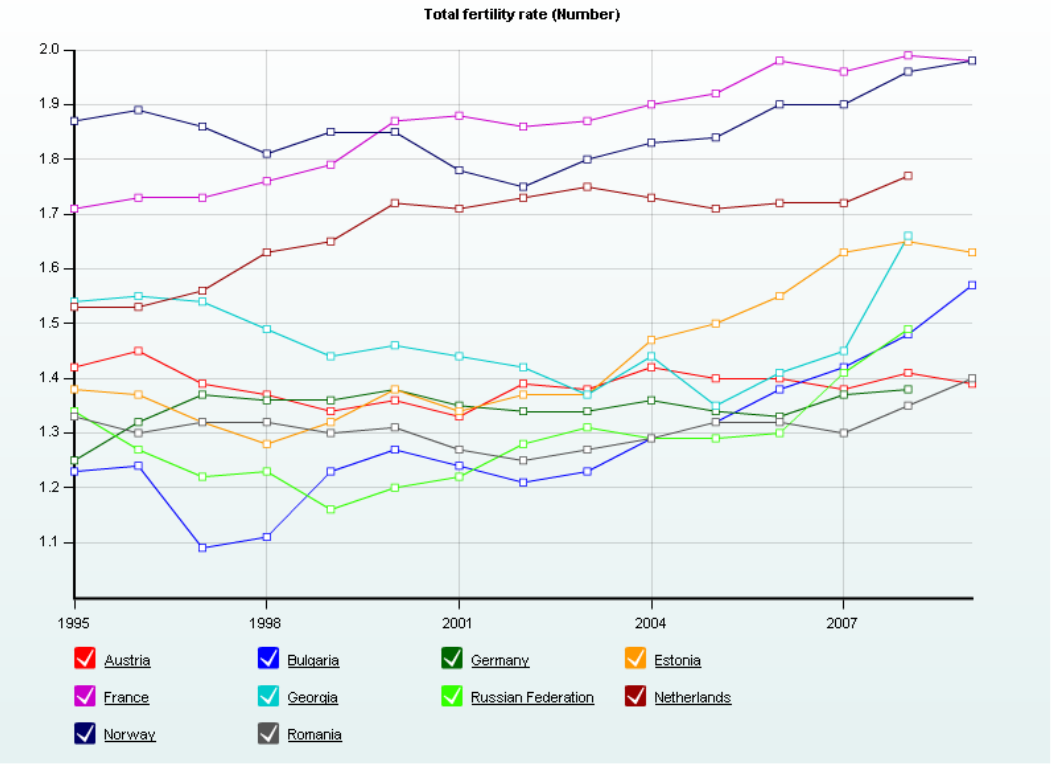

Chart type

Change the type of the chart Line/Point chart

\section{$\checkmark$}

\begin{tabular}{|c|c|}
\hline Individual chart configuration & \\
\hline Open chart in a new browser window & \begin{tabular}{|l|} 
Resizable version \\
\end{tabular} \\
\hline Legend & C Show $C$ Hide \\
\hline Chart background color 1 : & FFFFFF Preset (Default color) \\
\hline Chart background color 2: & E6F2F2 Preset (Default color) \\
\hline Line width & $1 \mathrm{px} \nabla$ \\
\hline Shape of the bullet that marks each graph point: & Square (Outline) $\doteq$ \\
\hline Size of the bullet that marks each graph point: & $6 \mathrm{px}=$ \\
\hline Graph 1 color: & FF0000 Preset (Default color) \\
\hline Graph 2 color: & 0000FF Preset (Default color) \\
\hline Graph 3 color: & 006600 Preset (Default color) \\
\hline Graph 4 color: & FF9900 Preset (Default color) \\
\hline Graph 5 color: & CCOOCC Preset (Default color) \\
\hline Graph 6 color: & $00 C C C C$ Preset (Default color) \\
\hline Graph 7 color: & 33FF00 Preset (Default color) \\
\hline Graph 8 color: & 990000 Preset (Default color) \\
\hline Graph 9 color: & 000066 Preset (Default color) \\
\hline Graph 10 color: & 555555 Preset (Default color) \\
\hline & Refresh chart \\
\hline
\end{tabular}

CDB Home | CDB Data | CDB About and Team | CDB Practical Notes | CDB Links | CDB Contact

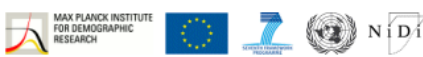

